\title{
ON THE RELATION BETWEEN CONDUCTIVITY AND CHLORIDES IN THE URINE
}

\author{
By H. C. GRAM* \\ (From the John Herr Musser Department of Research Medicine, University of \\ Pennsylvania, Philadelphia)
}

(Received for publication, May 19, 1924)

Previous papers by Gram and Norgaard (1) and Gram (2) and also by Atchley, Loeb, Benedict and Palmer (3) have shown in both normal and most pathological human sera a marked constancy in the ratio of $\mathrm{NaCl}$ concentration to the $\mathrm{NaCl}$ equivalent of conductivity. This is expressed as the ratio $\frac{[\mathrm{NaCl}]}{\mathrm{NaCl} \text { eq. }}$. A recent study by Pepper (4) has shown that in nephritis the relative proportion of non-chloride, non-urea constituents in the urine is increased.

It would seem that a determination of the ratio $\frac{[\mathrm{NaCl}]}{\mathrm{NaCl} \text { eq. }}$ in such urines would serve to throw light on whether this relative increase is due to non-chloride electrolytes or not.

In tables 1 and 2 we give the results of an examination of 11 normal and 11 nephritic urines respectively. All specimens were freshly voided and no ammoniacal decomposition had taken place. The ratio in normal urines of course is not nearly as fixed as in normal sera, but still has remained within the limits 0.84 and 0.63 in all cases, with an average of 0.726 .

In nephritic urines on the other hand the ratio $\frac{[\mathrm{NaCl}]}{\mathrm{NaCl} \text { eq. }}$ was with one exception lower than in any of the normal urines, varying between 0.67 and 0.34 with an average of 0.524 .

This marked discrepancy in the ratio cannot be attributed to the presence of albumin in the nephritic urines since the quantities of

* Robert M. Girvin, Fellow in Research Medicine and Fellow of the Rockefeller Foundation. 
TABLE 1

Eleven normal urines

\begin{tabular}{|c|c|c|c|c|}
\hline Name & Date & $\begin{array}{l}\mathrm{NaCl} \text { eq. } \\
\text { of conduct. }\end{array}$ & {$[\mathrm{NaCl}]$} & $\begin{array}{c}\begin{array}{c}\text { Ratio } \\
{[\mathrm{NaCl}]}\end{array} \\
\mathrm{NaCl} \mathrm{eq.}\end{array}$ \\
\hline & 1923 & per cont & per cent & \\
\hline H. C. G. & April 13 & 1.85 & 1.43 & 0.72 \\
\hline G. E. C. & April 14 & 0.59 & 0.39 & 0.66 \\
\hline J. & April 14 & 2.16 & 1.81 & 0.84 \\
\hline J.H. A. & April 21 & 1.89 & 1.31 & 0.69 \\
\hline D. H. M. & April 21 & 1.73 & 1.09 & 0.63 \\
\hline L. J. & April 23 & 1.91 & 1.51 & 0.79 \\
\hline P. & April 23 & 1.91 & 1.35 & 0.71 \\
\hline $\mathbf{K}$. & April 23 & 1.185 & 0.91 & 0.77 \\
\hline L. & June 4 & 1.54 & 1.10 & 0.71 \\
\hline P. P. & June 18 & 1.56 & 1.02 & 0.65 \\
\hline C. & September 10 & 1.96 & 1.61 & 0.82 \\
\hline \multirow{3}{*}{\multicolumn{4}{|c|}{ 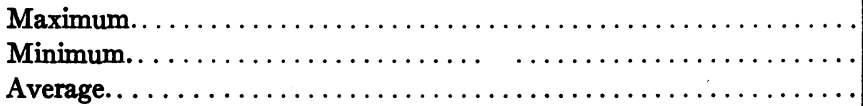 }} & 0.84 \\
\hline & & & & 0.63 \\
\hline & & & & 0.726 \\
\hline
\end{tabular}

TABLE 2

Eleven nephritic urines

\begin{tabular}{|c|c|c|c|c|c|}
\hline Name & Diagnosis & Date & $\begin{array}{l}\mathrm{NaCl} \text { of. } \\
\text { conduct. }\end{array}$ & {$[\mathrm{NaCl}]$} & $\begin{array}{c}\text { Ratio } \\
{\left[\begin{array}{l}\text { NaCl] } \\
\mathrm{NaCl} \text { eq. }\end{array}\right.}\end{array}$ \\
\hline & & 1923 & per cent & per cent & \\
\hline N. B. & Glomerulo-nephritis & April 26 & 0.49 & 0.27 & 0.55 \\
\hline G. $B$. & Nephritis & May 21 & 0.53 & 0.23 & 0.43 \\
\hline P. & Chronic nephritis & June 2 & 0.44 & 0.15 & 0.34 \\
\hline L. G. & Nephritis & June 6 & 0.36 & 0.20 & 0.56 \\
\hline J. N. & Nephritis & June 7 & 0.67 & 0.35 & 0.52 \\
\hline w. v. & Chronic nephritis & June 8 & 0.67 & 0.41 & 0.61 \\
\hline M. & Nephritis & June 20 & 0.91 & 0.42 & 0.46 \\
\hline M. T. & Nephritis & June 20 & 0.845 & 0.47 & 0.56 \\
\hline S. & Acute nephritis & June 20 & 0.73 & 0.43 & 0.59 \\
\hline A. $T$. & Chronic nephritis & September 5 & 0.51 & 0.34 & 0.67 \\
\hline S. M. & Chronic nephritis & September 5 & 0.425 & 0.20 & 0.47 \\
\hline \multirow{2}{*}{\multicolumn{5}{|c|}{ 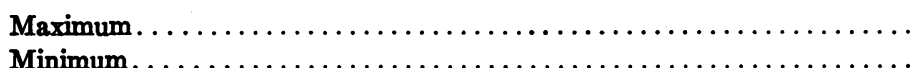 }} & 0.67 \\
\hline & & & & & 0.34 \\
\hline \multicolumn{5}{|l|}{ Averag } & 0.524 \\
\hline
\end{tabular}


albumin are too small to affect materially the ratio; besides any such influence would cause an increased, not a decreased ratio.

A lower concentration of non-electrolyte crystalloids, principally urea, would depress the ratio in nephritis but could not cause the difference observed, even if the urea decreased from 5 to 0 per cent. ${ }^{1}$

Only a few of these patients were placed on a diet poor in salts, so that this will not explain the decreased ratio $\frac{[\mathrm{NaCl}] \text {. }}{\mathrm{NaCl} \text { eq. }}$

No exact classification was attempted in diagnosis, but the material included both acute and chronic nephritis and sclerotic kidneys in different stages of severity.

\section{SUMMARY}

In nephritic urine the non-chloride electrolyte fraction is increased relative to the chloride fraction.

\section{BIBLIOGRAPHY}

1. Gram, H. C., and Norgaard, A. Jour. Biol. Chem., 1923, lvi, 429. Chloride and Conductivity Determinations on Plasma.

2. Gram, H. C. Jour. Biol. Chem., 1923, lvi, 593. Observations on the Regulation of Osmotic Pressure (Conductivity, Chlorides, Freezing Point, and Proteins of Serum).

3. Atchley, D. W., Loeb, R. F., Benedict, E. M. and Palmer, W. W. Arch. Int. Med., 1923, xxxi, 606 and 611. Physical and Chemical Studies of Human Blood Serum. I. A Study of Normal Subjects. II. A Study of TwentyNine Cases of Nephritis.

4. Pepper, O. H. P. Jour. Clinical Invest., 1924, i, 13. Studies on the Specific Gravity of the Urine.

1 To correct conductivity observed for urea we use the formula:

$$
C_{\mathrm{c}}=C_{\mathrm{o}} \cdot \frac{100}{100-d x}
$$

$\mathrm{C}_{\mathrm{o}}=$ corrected conductivity, $C_{\mathrm{o}}=$ observed conductivity, $d=$ constant, which is 1.1 for urea, $x=$ the percentage of urea. 